\title{
Influence of Sustainability Practices and Green Image on the Re-Visit Intention of Small and Medium-Size Towns
}

\author{
Pere Mercadé Melé ${ }^{1, *(\mathbb{D})}$, Jesús Molina Gómez ${ }^{2}$ and Maria José Sousa ${ }^{3,4}$ (D) \\ 1 Department of Statistics and Econometrics, University of Malaga, Campus el Ejido s/n, 29071 Malaga, Spain \\ 2 Department of Economics and Business, University of Malaga, Campus el Ejido s/n, 29071 Malaga, Spain; \\ jmolinag@uma.es \\ 3 Department of Political Science and Public Policies, ISCTE-Instituto Universitário de Lisboa, 1649-026 Lisboa, \\ Portugal; maria.jose.sousa@ISCTE-IUL.pt \\ 4 CinTurs, Algarve University, 8005-139 Faro, Portugal \\ * Correspondence: pmercade@uma.es
}

Received: 16 December 2019; Accepted: 22 January 2020; Published: 27 January 2020

\begin{abstract}
This study set a model to predict the effect of corporate social responsibility and green image on visit intention in small and medium-size towns (SMST). At present, there is a keen social awareness towards environmental problems, and cities are required to reduce their ecological footprint and make more sustainable use of natural resources. Increasingly, tourists are considering "green options" in their decision making. The questionnaire responses, obtained from a sample of 221 tourism in Malaga town (Spain) were analyzed using a Structural Equation Modelling (SEM) to test the research hypothesis related to the positive influence of sustainability practices, green image, trust with the intention of revisiting related to the loyalty of the destination. This study shows that there is a positive relationship between sustainability practices and re-visit intention and between the green image and re-visit intention, both directly and indirectly, through trust. Also, the fact that this relationship is more significant if it is part of the green image than if it is part of sustainability actions. To practice, this study provides managerial implications to help executives adopt green actions, thanks to their positive effects on tourist loyalty and the different way of manifesting this loyalty.
\end{abstract}

Keywords: sustainability practices; green image; trust; re-visit intention; SMST; structural equations model

\section{Introduction}

The tourism sector has been one of the protagonists of the economic and social growth and development of Spain in recent years [1]. With an excellent infrastructure of the services sector, Spain is the second most visited country in 2018, attended by thousands of tourists attracted by sun and beach tourism, climate, artistic and cultural heritage and gastronomy [1]. The leading world economies are betting on balanced and sustainable economic growth, which extends to all subsectors of tourism activity [2-4]. Small and medium-size towns (SMST) demand the approach of new lines of development and the need to reinvent a new growth model based on diversification, knowledge, innovation, productivity improvement and sustainability of the economy so that the objectives of balanced and sustainable growth are met, thus responding to the demands of the social, economic and environmental-related parties [5,6]. This is the case of sustainable tourism, which is defined according to the World Tourism Organization (UNWTO) as tourism that takes into account the current and future economic, social and environmental repercussions to meet the needs of visitors and industry, from the surroundings and the host communities. 
The increase in social awareness of environmental problems implies a model of responsible organizational management, which allows, not only to minimize the negative impacts generated by the activity of the city, but to generate shared value for both the company and its stakeholders and, therefore, for society in general $[7,8]$.

Every day there are more cities, which have gradually incorporated new practices that incorporate the development of positive awareness towards the care of the environment and communication strategies of their excellent work worldwide [9]. Thus, corporate social responsibility actions arise that aim to minimize the adverse effects on the physical environment, or to improve their quality and where cities strive to promote attitudes that respect the environment [10,11].

Malaga town (Spain) has been chosen as an object of study is because it meets all the requirements of SMST and has been developing environmental sustainability for 20 years since the mid-1990s, which began with the signing of the green card of Malaga. In 2015, an integrated sustainability plan 2020-2050 was carried out with Malaga being the first European city that contributed to this commitment.

In this research, a study will be carried out on the influence of the responsibility of the SMST from an ecological perspective, addressing sustainability practices, and the Green image, and its influence on re-visit intention. Therefore, it intends to address the knowledge of decision making from an environmental perspective as it is increasingly one of the main concerns in our society.

\section{Literature Review and Hypotheses}

\subsection{Sustainability Practices and Their Influence on Trust and Re-Visit Intention}

In recent years, there are more and more SMSTs that decide to bet on the application of social responsibility policies, underlining the importance of finding solutions to problems in social, environmental, and labor fields, as well as economic problems [12,13]. The application of these types of policies is linked, on multiple occasions, with sustainability practices. Moreover, although there are differences between the two, these concepts are inseparable. While sustainability refers to a social and economic macro-project that is aimed at the individual and social welfare of the population [14], social responsibility corresponds to the strategic and operational responses of the city concerning sustainability $[15,16]$.

Sustainability is defined as the satisfaction of current needs without compromising the ability of future generations to meet theirs, guaranteeing the balance between economic, environmental, and social welfare growth [17]. The definition of sustainability in the 21st century goes beyond Marketing 3.0, where consumers value social and environmental aspects when making their decisions [18]. For Kotler, Marketing 3.0 emerges as a need to respond to several factors: new technologies, the problems of globalization, and the interest to express creativity, values, and spirituality. In this context, sustainability practices have become one of the most important factors influencing the decision-making process and tourist perceptions $[19,20]$. At present, there are more and more SMSTs that focus on the need for harmony with the environment and on reducing environmental footprints [21].

The SMST that demonstrate social responsibility through actions in favor of society will be positioning themselves as cities that will enjoy the respect and admiration of the general society $[10,22]$.

In short, sustainability initiatives are a source of differentiation for the SMST that generates economic advantages $[23,24]$. Loyalty strategies involve differentiation concerning competition, listening to tourists, and offering news, improvements, and better service, which means not only retaining old tourists, but also new and potential tourists [25-27]. Tourists value the efforts of the SMST to participate in programs of energy saving, recycling, and renewable energy etc., in addition to other activities. Therefore, this effort is reflected in tourist's re-visit intention [28,29].

Based on this, we can establish the following hypothesis:

Hypothesis 1: Sustainability practices positively influences re-visit intention. 
The confidence of tourists is the expectation of positive results that one can perceive based on the actions expected from another party in the interaction characterized by uncertainty [30]. According to Signaling Theory [31], the responsible and sustainable actions carried out by the SMST are equivalent to the signals sent by a city to reduce the uncertainty that may affect the visiting decisions of tourists. This theory also states that cities emit different types of signals related to their competences or ethical values [32]. Tourists, based on these signals, will decide if the SMTS in question shares the same interpretation of the rules [11].

Sustainability practices generate beneficial relationships between tourists and generate trust in the city [33]. Trust is a mediating element between the sustainable activities of cities and re-visit intention $[27,33]$. Within the context of our research, the second hypothesis is formulated as follows:

Hypothesis 2: Sustainability practices positively influence consumers trust.

\subsection{Green Image and Its Influence on Trust and Re-Visit Intention}

Green image is the set of perceptions of a city in the minds of tourists, linked to environmental commitments and concerns [34]. Therefore, this definition refers to the subjective perception of tourists regarding the image of a city about the environment. There are more and more SMSTs that invest more resources in managing the most valuable assets they own, as is the case of the green image that, in recent years, has become increasingly important, creating value for the city and providing a significant asset [35]. green image is defined as the mental construction of the environmental aspects of a city by citizens, which will condition, to a greater or lesser extent, how individuals will relate and act around the city [36]. The images of the SMST are elaborated on using perception, experience, mental constructions, and memory [37]. These associations maintain absolute stability and are influenced by the changes that occur both in the social environment and in the strategies of the city or the competition [38]. In this sense, the SMST increasingly bet on having a green image, that is, respectful of the environment and society [34]. There are examples of the "green attributes" of a city, such as the possibility of more sustainable traffic, recycling bins, or cleaner air, which can have a positive impact on the green image [39]. Therefore, it is expected that green image can affect both confidence and re-visit intention [40]. The green image will reflect the values of the SMST in an increasingly global world and will influence the positioning of the city, and therefore, its confidence and its intention to re-visit the city. An excellent green image will act as a differentiating element when choosing a tourist destination. The more sustainable the image of an SMST, the higher the willingness to depend on the image based on the belief or the expectation resulting from its environmental trust. Some authors propose green image as an essential element that is associated with visiting, being one of the determining elements for consumer loyalty $[28,41]$. This translates into our third and fourth work hypothesis:

Hypothesis 3: Green image positively influences re-visit intention.

Hypothesis 4: Green image positively influences tourist trust.

\subsection{The Influence of Trust in the Re-Visit Intention}

Marketing literature states that, if tourists have confidence with the chosen city, they will increasingly be willing to re-visit this destination, and finally become a loyal tourist $[5,42,43]$. Trust is considered one of the antecedents of re-visit intention $[27,28,44,45]$.

Hypothesis 5: Tourist trust positively influences re-visit intention.

Therefore, this model shows the relationship between sustainability practices and re-visit intention, and between the green image and re-visit intention, through trust. 
In Figure 1 establishes the research model, which includes all of the causal relationships proposed in them:

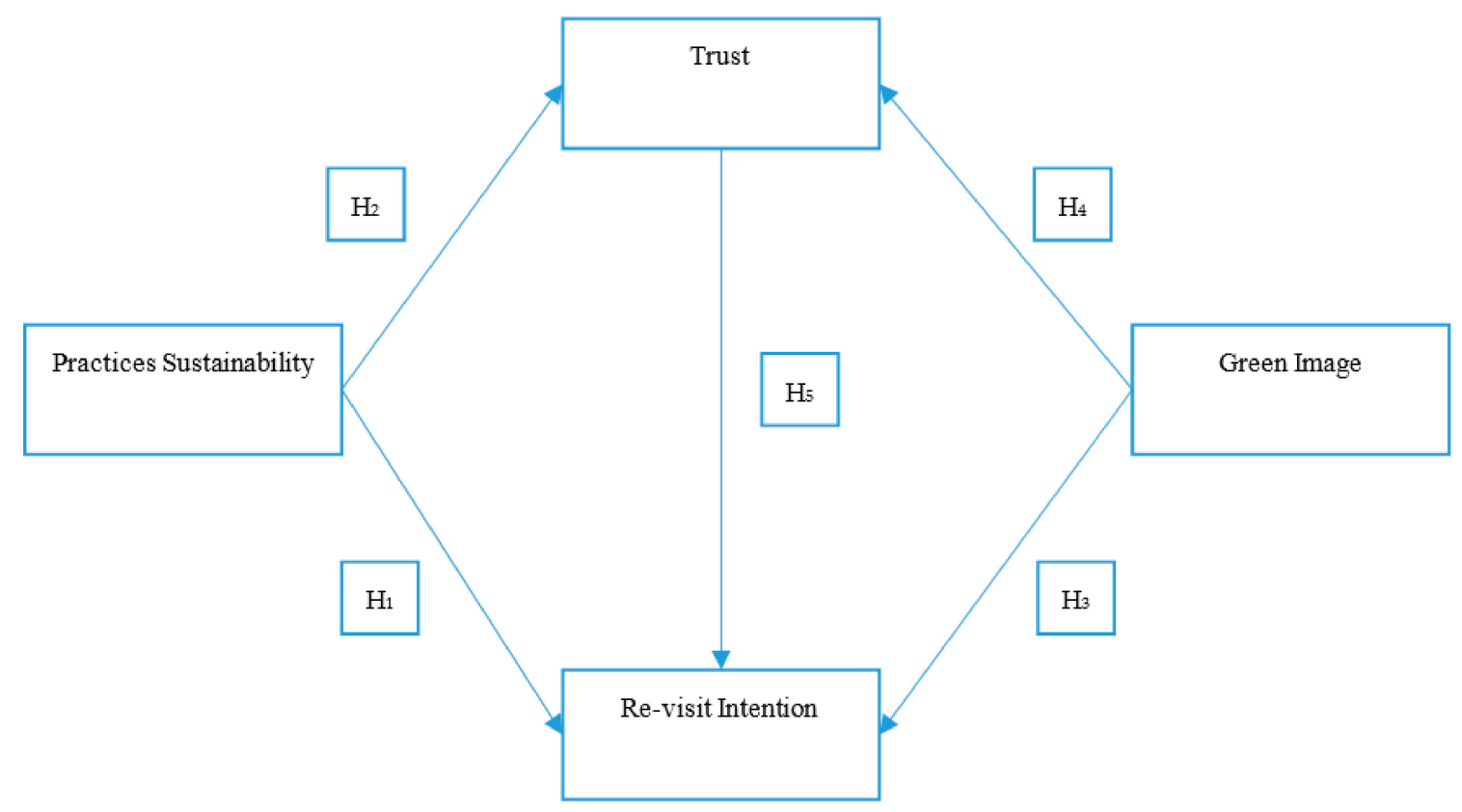

Figure 1. The theoretical model proposed.

\section{Materials and Methods}

\subsection{Data Collection and Sample}

A sample of tourists who have visited Malaga in the past were surveyed with a structured questionnaire to validate the research hypotheses [28]. According to official sources of the Tourism Board of the Costa del Sol, a total of 12.5 million tourists visit Malaga in 2018, of which $70 \%$ have repeated. In this investigation the universe is the tourists who have visited Malaga again. The first part of the questionnaire explaining the research; the second part contained the questions of the items which explained each of the constructs, and the third part contained sociodemographic classifications. In order to guarantee a more excellent representation of data, a convenience sample was used, precisely a multi-stage sampling by quotas was carried out based on the age and gender of consumers [9]. Convenience sampling is suitable when it is difficult to obtain a complete sampling frame [37]. Participants took eight min, on average, to complete the questionnaire. The questionnaire was tested using a pre-test conducted on a sample of 20 tourists who had visited Malaga before the months of January and February in 2018, which made it possible to clarify the questions. The survey was carried out between April and September 2018. These surveys were carried out at the airport of Malaga at the tourist's entrance, with the intention of knowing if the practices of sustainability actions and the green image of the destination have had a influence on the reason for revisiting. Finally, 221 surveys were obtained, with women representing $52.1 \%$ and men representing $48.9 \%$. Data error for the estimate was in the proportion of $6.6 \%$, with a confidence level of $95 \%$ and the most unfavorable hypothesis $(p=q=0.5)$. Eleven-point-eight percent of the respondents were under the age of 24 , with $42.5 \%$ aged between 25 and 44 and $45.7 \%$ being over the age of 45 years. The average age of participants was 42.13 (standard deviation 12.07). The respondents' level of education was: $17.6 \%$ have basic studies, $42.1 \%$ have secondary education and $40.3 \%$ have university studies. 


\subsection{Small Medium-Size Town-SMST: Sustainability Malaga}

Malaga was chosen as a study objective because it meets all the SMST parameters and also has been betting on environmental sustainability for 20 years. Since the mid-1990s, when the green card of Malaga was signed and the first Agenda 21 was held, where recommendations made at the United Nations Conference in Rio de Janeiro were collected, different actions that have an impact on the consumption of waters and the use of new technologies in urban environments such as Smart Cities were followed $[46,47]$. In fact, in 2008, the commitment by the city to reduce $\mathrm{CO}_{2}$ emissions by at least $40 \%$ over the 2030 horizon was signed and adopted a comprehensive approach to address climate change mitigation and adaptation. In 2015, the city of Malaga published Agenda 21, carrying out an integrated sustainability plan 2020-2050, with Malaga being the first European city to have this document.

\subsection{Measurement development}

The items and the constructs used in the research appear in Table 1 and have been obtained from previous literature. Mainly, three items based on Brown and Dacin [48] were used to measure sustainability practices. Three items were based on Amores et al. (2014) [49] to measure green image. To asses trust, four items based on the study conducted by Sirdeshmukh et al. (2002) [50] were used. Finally, four items based on studies conducted by Maxham and Netemeyer (2002) [51] were used to measure re-visit intention. The next table shows the scales used for each construct. The latent construct was measured using multi-attribute scales, specially seven-point Likert scales, where one means "totally disagree" and seven means "totally agree." The nature of epistemological relationships is reflective as they are more suitable for defining characteristics of attitude and personality [52].

Table 1. Confirmatory factor analysis. Psychometric properties.

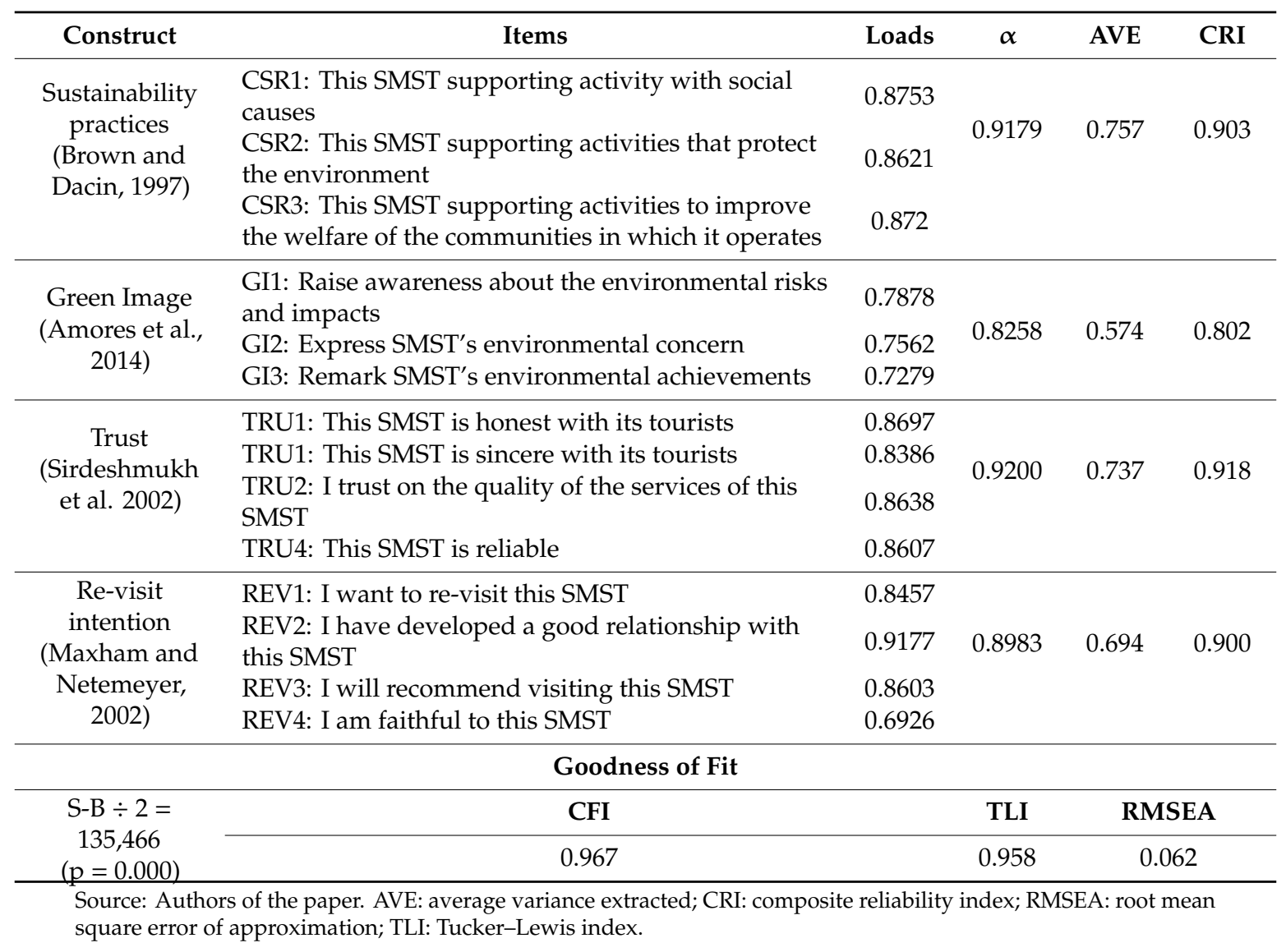




\section{Results}

\subsection{Analysis of the Psychometric Properties of the Measurement Model}

In order to have a comprehensive assessment of the theoretical model, the psychometric properties are evaluated, the leading measures of validity, reliability, and goodness and the correlations between constructs. The software used for the estimate is STATA 15.1. The composite reliability index (CRI) is higher than 0.7 [53], Cronbach's Alpha $(\alpha)$ is higher than 0.7 [54], and the average variance extracted is higher than 0.5 [53]. The measures of validity are also optimal, the coefficients of standardized loadings are more significant than 0.5 , and their means are greater than 0.7 [55]; therefore, convergent validity is confirmed. In Table 2 , the discriminant validity of the measurement model is verified. None of the confidence intervals of the correlations contains the value of one [56], and the average variance extracted (AVE) is larger than the shared variance, and so it shows discriminant validity, that is to stay, a construct is different from the other constructs [55]. About the measures of goodness, the root mean square error of approximation (RMSEA) is lower than 0.08, and the Tucker-Lewis index (TLI) and the comparative fit index (CFI) are higher than 0.9 [57]. The only statistic which does not comply is the $\chi^{2}$, but we do not consider it a severe limitation because it is susceptible to sample size (Cheung and Rensvold, 2002) and often rejects the hypothesis of a good fit even if the hypothesis contract is significant in the model [58].

Table 2. Test of discriminant validity.

\begin{tabular}{ccccc}
\hline Construct & $\begin{array}{c}\text { Sustainability } \\
\text { Practices }\end{array}$ & Green Image & Trust & Re-Visit Intention \\
\hline Sustainability practices & $\mathbf{0 . 7 5 7}$ & 0.069 & 0.192 & 0.254 \\
Green Image & $(0.132 ; 0.397)$ & $\mathbf{0 . 5 7 4}$ & 0.509 & 0.565 \\
Trust & $(0.322 ; 0.555)$ & $(0.596 ; 0.833)$ & $\mathbf{0 . 7 3 7}$ & 0.609 \\
Re-visit Intention & $(0.395 ; 0.612)$ & $(0.662 ; 0.842)$ & $(0.697 ; 0.864)$ & $\mathbf{0 . 6 9 4}$ \\
\hline
\end{tabular}

Source: Authors of the paper. The main diagonal (in bold) represent average variance extracted (AVE). Confidence intervals $(\alpha=0.5)$ for correlations are reported below the main diagonal. Shared variances (square correlations) are reported above the main diagonal.

\subsection{Analysis of the Structural Relationships and Contrast in the Hypotheses Proposed}

Table 3 shows standardized coefficients of the structural relationships in the theoretical model proposed.

Table 3. Evaluation of structural models.

\begin{tabular}{ccccc}
\hline Hypothesis & Structural Relationship & Coef. & t-Student & Contrast \\
\hline $\mathrm{H}_{1}$ & Sustainability $\rightarrow$ Re-visit & 0.2579 & $5.01^{* * *}$ & Supported \\
\hline $\mathrm{H}_{2}$ & Sustainability $\rightarrow$ Trust & 0.3120 & $6.18^{* * *}$ & Supported \\
\hline $\mathrm{H}_{3}$ & Green Image $\rightarrow$ Re-visit & 0.4363 & $3.93^{* * *}$ & Supported \\
\hline $\mathrm{H}_{4}$ & Green Image $\rightarrow$ Trust & 0.6684 & $11.09^{* * *}$ & Supported \\
\hline $\mathrm{H}_{5}$ & Trust $\rightarrow$ Re-visit & 0.3886 & $3.56^{* * *}$ & Supported \\
\hline \multicolumn{5}{c}{ Note: } \\
\end{tabular}

The answers are given by users who answered this survey present a direct relationship between sustainability practices and re-visit intention (H1 is supported) and between green image and re-visit intention (H3 is supported). Moreover, an indirect relationship between sustainability practices or green image and re-visit intention is presented through a trust $(\mathrm{H} 2, \mathrm{H} 4$, and $\mathrm{H} 5$ are supported). Furthermore, the relationship between the green image and trust is the strongest of all $(\beta=0.6684)$, followed by the causal relationship between green image and re-visit intention $(\beta=0.4363)$. As can be 
observed in Table 4, tourists present a direct effect between green image and re-visit of 0.4363 , which is significantly higher than the direct effect between sustainability practices and re-visit intention $(0.2579)$. In this sense, the indirect effect produced between green image and re-visit intention through trust is 0.2597; and between sustainability practices and re-visit intention through trust is 0.1212 (significantly lower). Finally, the total effect on re-visit intention is higher based on the green image (0.6960) than if it is initiated by sustainability practices $(0.3791)$.

Table 4. Direct, indirect, and total effects.

\begin{tabular}{cccc}
\hline & Direct Effect & Indirect Effect & Total Effect \\
\hline Sustainability practices-Re-visit Intention & 0.2579 & Sustainability-Trust-Re-visit: 0.1212 & 0.3791 \\
\hline Green Image-Re-visit Intention & 0.4363 & Green Image-Trust-Re-visit: 0.2597 & 0.6960 \\
\hline
\end{tabular}

Source: Authors of the paper.

Figure 2 shows the model with its respective structural coefficients.

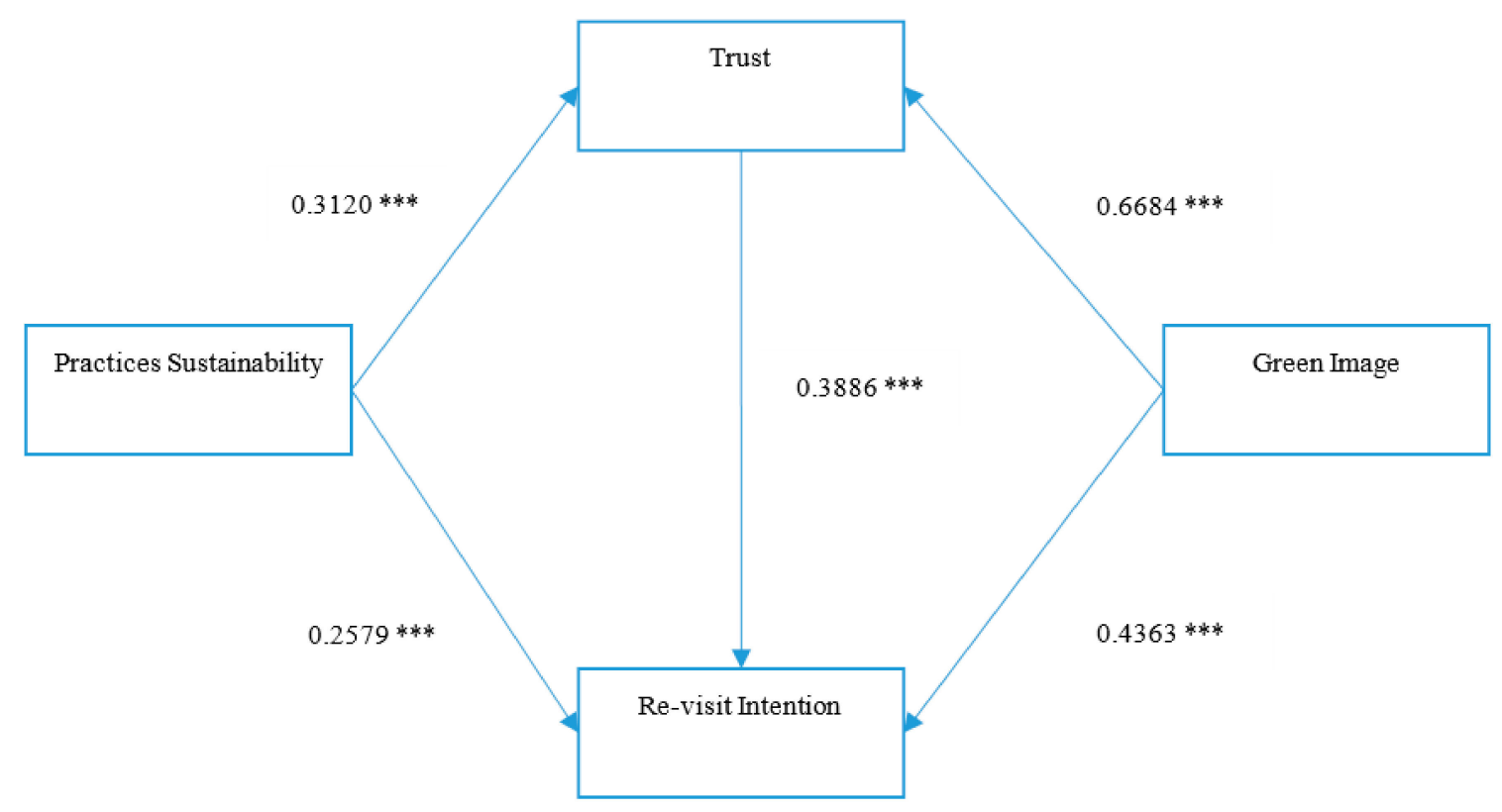

Note: ${ }^{* * *} p$-value $<0.01$. Source: Authors of the paper.

Figure 2. Structural model. Source: Authors of the paper.

\section{Conclusions, Discussions, and Implications for Management}

There are currently many cities that have joined new practices that introduce the development of a positive awareness towards the conservation and care of the environment and of course, to generate communication channels to give visibility to this current as necessary $[9,59]$. This is where corporate social responsibility actions start that not only minimize the adverse effects on the environment but also seek to create more sustainable environments combining the quality of life and respect with the environment, thus reinforcing socially responsible actions [2,4].

The study has been carried out by influencing the responsibility of the SMST from an ecological perspective in both sustainability practices and the green image and how they directly influence the re-visit intention and indirectly through the trust. This analysis is intended to understand the behavior of tourists about this critical aspect in today's society $[11,27,60]$.

The conclusion of this study shows that there is a direct and positive relationship between sustainability practices and green image $[11,60]$, on the behavior of tourists, in re-visit intention and also with higher weight in the direct relationship than in the indirect relationship through trust. 
While it is true that the literature tells us about a direct positive relationship between sustainability practices and the variables of tourist behavior such as loyalty, satisfaction, and trust [34,61], our study explains more concretely and descriptively the behavior of the tourist before this type of marketing strategies.

Following the conclusions of the study, we observe that the green image has more strength over re-visitation both directly and indirectly, compared to sustainability practices. Reviewing the literature, Flavian et al. (2005) [62] raise a positive relationship of the brand image concerning satisfaction, loyalty, and trust, being verified in this study in a more particular way and especially making a comparison. Various empirical studies and different authors such as Martínez (2015) [27] or Chen (2010) [34] have analyzed these relationships and established positive direct relationships between these elements.

The choice of Malaga as the object of our study is because it has been working on environmental sustainability for 20 years, starting in the mid-1990s with the signing of the green card of Malaga. This type of action in the city confirms our research, as sustainability practices generate confidence in the tourist, and this can affect specific behavior, but what changes the behavior of our tourists is sustainability practices on an ongoing basis, generating a green image of destiny, ultimately having a more significant influence on their behavior. The city of Malaga in 2015 publishes Agenda 21 carrying out an integrated sustainability plan 2020-2050, with Malaga being the first European city to have this document. Working not in isolation but integrated with all the agents of the destination, for this purpose, "the provincial forum of socially responsible companies" is created, generating a solid and integrating ecosystem of all the agents involved [14].

We can affirm that currently, tourists are increasingly aware of environmental problems and are more aware of their decision making in the tourism sector, not only in the choice of destination but in their loyalty.

In fact, in this study we demonstrate one of the multiplier and collateral effects that investment in sustainability has, not only the effect on the environment or on the quality of life in the destination, but the attraction and promotion that this implies in the destination $[16,17,61]$.

About SMST, they need to implement long-term strategic plans that incorporate environmental policies and green marketing actions to strengthen the trust, satisfaction, and loyalty of their consumers in order to create positive impacts [63] or give the right image to their groups of interest $[64,65]$ generating in this way a global green image. With all this, from the marketing perspective, it is essential to point out that it is not only crucial for SMSTs to implement green marketing techniques through CSR, but also it is important to know how to communicate them [14] and take environmentally conscious tourists to visit cities of these characteristics. The synergy of these actions will be the one that will lead the SMST to obtain a faithful, confident, and satisfied tourist, and with this, to transmit the right brand image that will consequently impact on obtaining benefits in the social environment and economic of the city [17].

\subsection{Limitations of the Investigation}

About the limitations existing in this paper, it should be added that the population sample has been 221 tourists. With a larger sample, different segmentations could be made to analyze comparisons between different moderating effects. Another limitation focuses on analyzing a single city where sustainability practices and green image have been developing over time, and it would be interesting to have taken more cities with very similar characteristics to see if these hypotheses are met.

\subsection{Future Lines of Research}

First, in order to achieve more optimal values in this study, it is proposed to expand the sample evaluated. For this, the questionnaire will be disseminated through social networks. Besides, the sample can be extended to other cities, in order to assess whether there are differences in the behavior of the data. It would be convenient to analyze the model of such research in different cities, based on multi-group analysis where the cities would be the moderating effect. Since the cultural background of 
the individual, making a decision could significantly influence their selection [66] as cultures disagree for their orientation of the factors that affect perception.

Secondly, it is proposed to carry out a cluster analysis in order to group the individuals studied and analyze their behavior in their decision making. It would be interesting to study the green consumer, analyze their preferences and their sociodemographic data. This information would be of high relevance for the cities where they intend to attract this type of audience when launching their communication campaigns, helping them in their segmentation of the target audience.

Author Contributions: This study has been designed and performed by all of the authors. P.M.M. collected and analyzed the data. All of the authors wrote the introduction, literature review and hypothesis, discussion, and conclusions. All authors have read and agreed to the published version of the manuscript.

Funding: This research was partially funded by the Plan Andaluz de Investigación, Desarrollo e Innovación, Grupo SEJ-124 (Spain).

Acknowledgments: The authors would like to acknowledge the participants in the study and the reviewers.

Conflicts of Interest: The authors declare no conflict of interest.

\section{References}

1. UNWTO. Report on Tourism and Culture Synergies; UNWTO: Madrid, Spain, 2018.

2. Font, X.; Lynes, J. Corporate social responsibility in tourism and hospitality. J. Sustain. Tour. 2018, 26, 1027-1042. [CrossRef]

3. Noronha, T.; Vaz, E.; Nijkamp, P. Small towns of hope and glory. In Small Towns in the Rural World; Noronha, T., Vaz, E., Leeuwen, S., Nijkamp, P., Eds.; Ashgate: London, UK, 2013.

4. Noronha, T.; Vaz, E. Framing urban habitats: The small and medium towns in the peripheries. Habitat Int. 2015, 45, 147-155. [CrossRef]

5. Homburg, C.; Stierl, M.; Bornemann, T. Corporate social responsibility in business-to-business markets: How organizational customers account for supplier corporate social responsibility engagement. J. Mark. 2013, 77, 54-72. [CrossRef]

6. Vaz, E.; Noronha, M.T.; Nijkamp, P. Exploratory landscape metrics for agricultural sustainability. Agroecol. Sustain. Food Syst. 2014, 38, 92-108. [CrossRef]

7. Lee, J.S.; Hsu, L.T.; Han, H.; Kim, Y. Understanding how consumers view green hotels: How a hotel's green image can influence behavioural intentions. J. Sustain. Tour. 2010, 18, 901-914. [CrossRef]

8. Han, H.; Hyun, S.S. What influences water conservation and towel reuse practices of hotel guests? Tour. Manag. 2018, 64, 87-97. [CrossRef]

9. Mercadé-Melé, P.; Molina-Gomez, J.; Garay, L. To green or not to green: The influence of green marketing on consumer behaviour in the hotel industry. Sustainability 2019, 11, 4623.

10. Garay, L.; Font, X.; Corrons, A. Sustainability-oriented innovation in tourism: An analysis based on the decomposed theory of planned behavior. J. Travel Res. 2019, 58, 622-636. [CrossRef]

11. Garay, L.; Font, X. Doing good to do well? Corporate social responsibility reasons, practices, and impacts in small and medium accommodation enterprises. Int. J. Hosp. Manag. 2012, 31, 329-337. [CrossRef]

12. Mercadé-Melé, P.; Jiménez, S.M.; Fernández-Morales, A. Influencia de las prácticas de responsabilidad social corporativa en la actitud del consumidor: Análisis comparado de Mercadona, Carrefour y Eroski. Rev. Empresa Fam. 2014, 4, 73-88. [CrossRef]

13. Mercadé-Melé, P.; Molinillo, S.; Fernández-Morales, A. The influence of the types of media on the formation of perceived CSR. Span. J. Mark. -ESIC 2017, 21, 54-64. [CrossRef]

14. Tremblay, P. Sustainable tourism. In Tourism Collaboration and Partnerships: Politics, Practice, and Sustainability; Channel View Publications: Bristol, UK, 2000; Volume 2, p. 314.

15. Font, X.; Garay, L.; Jones, S. Sustainability motivations and practices in small tourism enterprises in European protected areas. J. Clean. Prod. 2016, 137, 1439-1448. [CrossRef]

16. Font, X.; McCabe, S. Sustainability and marketing in tourism: Its contexts, paradoxes, approaches, challenges, and potential. J. Sustain. Tour. 2017, 25, 869-883. [CrossRef]

17. World Travel \& Tourism Council. Travel \& Tourism: Economic Impact 2018, Albania; World Travel \& Tourism Council (WTTC): London, UK, 2018. 
18. Kotler, P. Reinventing marketing to manage the environmental imperative. J. Mark. 2011, 75, $132-135$. [CrossRef]

19. Vaz, M.T.N.; Viaene, J.; Wigier, M. (Eds.) Innovation in the Small Firms and Dynamics of Local Development; Scholars' Press: Warsaw, Poland, 2004.

20. Xu, X.; Gursoy, D. A conceptual framework of sustainable hospitality supply chain management. J. Hosp. Mark. Manag. 2015, 24, 229-259. [CrossRef]

21. Mercadé-Melé, P.; Molinillo, S.; Fernández-Morales, A.; Porcu, L. CSR activities and consumer loyalty: The effect of the type of publicizing medium. J. Bus. Econ. Manag. 2018, 19, 431-455. [CrossRef]

22. Font, X.; Tribe, J. Promoting green tourism: The future of environmental awards. Int. J. Tour. Res. 2001, 3, 9-21. [CrossRef]

23. Bonilla Priego, M.J.; Najera, J.J.; Font, X. Environmental management decision-making in certified hotels. J. Sustain. Tour. 2011, 19, 361-381. [CrossRef]

24. Sampaio, A.R.; Thomas, R.; Font, X. Why are some engaged and not others? Explaining environmental engagement among small firms in tourism. Int. J. Tour. Res. 2012, 14, 235-249. [CrossRef]

25. Kang, J.; Hustvedt, G. Building trust between consumers and corporations: The role of consumer perceptions of transparency and social responsibility. J. Bus. Eth. 2014, 125, 253-265. [CrossRef]

26. Watson, G.F.; Beck, J.T.; Henderson, C.M.; Palmatier, R.W. Building, measuring, and profiting from customer loyalty. J. Acad. Mark. Sci. 2015, 43, 790-825. [CrossRef]

27. Martínez, P. Customer loyalty: Exploring its antecedents from a green marketing perspective. Int. J. Contemp. Hosp. Manag. 2015, 27, 896-917. [CrossRef]

28. Chancellor, C.; Cole, S. Using a geographic information system to visualize travel patterns and market research data. J. Travel Tour. Mark. 2008, 25, 341-354. [CrossRef]

29. Martínez, P.; Rodríguez, I. CSR and customer loyalty: The roles of trust, customer identification with the company, and satisfaction. Int. J. Hosp. Manag. 2013, 35, 89-99. [CrossRef]

30. Bhattacharya, R.; Devinney, T.M.; Pillutla, M.M. A formal model of trust based on outcomes. Acad. Manag. Rev. 1998, 23, 459-472. [CrossRef]

31. Spence, M. Competitive and optimal responses to signals: An analysis of efficiency and distribution. J. Econ. Theory 1974, 7, 296-332. [CrossRef]

32. Gurviez, P.; Korchia, M. Proposition d'une échelle de mesure multidimensionnelle de la confiance dans la marque. Rech. Appl. Mark. 2002, 17, 41-61. [CrossRef]

33. Chaudhuri, A.; Holbrook, M.B. The chain of effects from brand trust and brand affect to brand performance: The role of brand loyalty. J. Mark. 2001, 65, 81-93. [CrossRef]

34. Chen, Y.S. The drivers of green brand equity: Green brand image, green satisfaction, and green trust. J. Bus. Eth. 2010, 93, 307-319. [CrossRef]

35. Domínguez, J.A.; Noronha, T.D.; Vaz, E. Sustainability in the trans-border regions? The case of Andalusia-Algarve. Int. J. Glob. Environ. Issues 2015, 14, 151-163. [CrossRef]

36. Capriotti, P. Communicating corporate social responsibility through the internet and social media. Handb. Commun. Corp. Soc. Responsib. 2011, 1, 358-378.

37. Pérez-Tapia, G.; Mercadé-Melé, P.; Almeida-García, F. Corporate image and destination image: The moderating effect of the motivations on the destination image of Spain in South Korea. Asia Pac. J. Tour. Res. 2019, 24, 70-82. [CrossRef]

38. Ko, E.; Hwang, Y.K.; Kim, E.Y. Green marketing functions in building a corporate image in the retail setting. J. Bus. Res. 2013, 66, 1709-1715. [CrossRef]

39. Jeong, H.J.; Paek, H.J.; Lee, M. Corporate social responsibility effects on social network sites. J. Bus. Res. 2013, 66, 1889-1895. [CrossRef]

40. Namkung, Y.; Jang, S.S. Effects of restaurant green practices on brand equity formation: Do green practices really matter? Int. J. Hosp. Manag. 2013, 33, 85-95. [CrossRef]

41. Andreassen, T.W.; Lindestad, B. The effect of corporate image in the formation of customer loyalty. J. Serv. Res. 1998, 1, 82-92. [CrossRef]

42. Lin, C.P.; Chen, S.C.; Chiu, C.K.; Lee, W.Y. Understanding purchase intention during product-harm crises: Moderating effects of perceived corporate ability and corporate social responsibility. J. Bus. Eth. 2011, 102, 455. [CrossRef] 
43. Pérez, A.; Rodriguez del Bosque, I. Corporate social responsibility and customer loyalty: Exploring the role of identification, satisfaction, and type of company. J. Serv. Mark. 2015, 29, 15-25. [CrossRef]

44. Han, H.; Lee, M.J.; Kim, W. Promoting towel reuse behaviour in guests: A water conservation management and environmental policy in the hotel industry. Bus. Strategy Environ. 2018, 27, 1302-1312. [CrossRef]

45. Verhoef, P.C. Understanding the effect of customer relationship management efforts on customer retention and customer share development. J. Mark. 2003, 67, 30-45. [CrossRef]

46. Carillo-Aparicio, S.; Heredia-Larrubia, J.R.; Perez-Hidalgo, F. SmartCity Malaga, a real-living lab and its adaptation to electric vehicles in cities. Energy Policy 2013, 62, 774-779. [CrossRef]

47. Shomali, A.; Pinkse, J. The consequences of smart grids for the business model of electricity firms. J. Clean. Prod. 2016, 112, 3830-3841. [CrossRef]

48. Brown, T.J.; Dacin, P.A. The company and the product: Corporate associations and consumer product responses. J. Mark. 1997, 61, 68-84. [CrossRef]

49. Amores-Salvadó, J.; Martín-de Castro, G.; Navas-López, J.E. Green corporate image: Moderating the connection between environmental product innovation and firm performance. J. Clean. Prod. 2014, 83, 356-365.

50. Sirdeshmukh, D.; Singh, J.; Sabol, B. Consumer trust, value, and loyalty in relational exchanges. J. Mark. 2002, 66, 15-37. [CrossRef]

51. Maxham, J.G., III; Netemeyer, R.G. A longitudinal study of complaining customers' evaluations of multiple service failures and recovery efforts. J. Mark. 2002, 66, 57-71. [CrossRef]

52. Fornell, C.; Bookstein, F.L. Two structural equation models: LISREL and PLS applied to consumer exit-voice theory. J. Mark. Res. 1982, 19, 440-452. [CrossRef]

53. Fornell, C.; Larker, D.F. Structural equation models with unobservable variables and measurement error. J. Mark. Res. 1981, 18, 39-50. [CrossRef]

54. Cronbach, L.J. Coefficient alpha and the internal structure of tests. Psychometrika 1951, 16, 297-334. [CrossRef]

55. Hair, J.F.; Black, W.C.; Babin, B.J.; Anderson, R.E.; Tatham, R. Multivariate Data Analysis; Prentice-Hall: Upper Saddle River, NJ, USA, 2005.

56. Anderson, J.; Gerbing, D. The use of pledges to build and sustain commitment in distribution channels: A review and recommended two-step approach. Psychol. Bull. 1988, 103, 411-423. [CrossRef]

57. Hu, L.T.; Bentler, P.M. Cutoff criteria for fit indexes in covariance structure analysis: Conventional criteria versus new alternatives. Struct. Equ. Model. Multidiscip. J. 1999, 6, 1-55. [CrossRef]

58. Bentler, P.M.; Bonett, D.G. Significance tests and goodness of fit in the analysis of covariance structures. Psychol. Bull. 1980, 88, 588. [CrossRef]

59. Almeida, F.; Domínguez, J.; Mercadé-Melé, P. Image analysis of a tourist destination. In Co-Creation and Well-Being in Tourism; Springer: Berlin/Heidelberg, Germany, 2017.

60. Martinez, P.; Herrero, A.; Gómez, R. Customer responses to environmentally certified hotels: The moderating effect of environmental consciousness on the formation of behavioral intentions. J. Sustain. Tour. 2018, 26, 1160-1177. [CrossRef]

61. Gupta, A.; Dash, S.; Mishra, A. All that glitters is not green: Creating trustworthy ecofriendly services at green hotels. Tour. Manag. 2019, 70, 155-169. [CrossRef]

62. Flavián, C.; Guinaliu, M.; Torres, E. The influence of corporate image on consumer trust: A comparative analysis in traditional versus internet banking. Int. Res. 2005, 15, 447-470. [CrossRef]

63. Porter, M.; Kramer, M. Estrategia y Sociedad. Harv. Bus. Rev. 2006, 84, 42-56.

64. Lichtenstein, D.R.; Drumwright, M.E.; Braig, B.M. The effect of corporate social responsibility on customer donations to corporate-supported nonprofits. J. Mark. 2004, 68, 16-32. [CrossRef]

65. Marín, L.; Cuestas, P.J.; Román, S. Determinants of consumer attributions of corporate social responsibility. J. Bus. Eth. 2016, 138, 247-260. [CrossRef]

66. Robbins, S.P.; Judge, T.A. Organizational Behavior; Pearson Education: London, UK, 2013.

(C) 2020 by the authors. Licensee MDPI, Basel, Switzerland. This article is an open access article distributed under the terms and conditions of the Creative Commons Attribution (CC BY) license (http://creativecommons.org/licenses/by/4.0/). 